ОСНОВНІ ПРИНЦИПИ МАСОВОГО ТА ДИСТАНЦІЙНОГО НАВЧАННЯ БАКАЛАВРІВ ІЗ КІБЕРБЕЗПЕКИ В УМОВАХ ОСВІТНЬО-ЦИФРОВОГО СЕРЕДОВИЩА ЗАСОБАМИ ҮОUТUВЕ-КАНАЛІВ 3 ІНТЕРАКТИВОМ ДЛЯ САМОПЕРЕВІРКИ ОТРИМАНИХ ЗНАНЬ ТА 3 ВИКОРИСТАННЯМ ЕЛЕКТРОННИХ ОНЛАЙН-КАЛЬКУЛЯТОРІВ

\title{
SIGNIFICANT MASS AND DISTANCE EDUCATION BACHELOR OF CYBERSECURITY UNDER EDUCATIONAL AND MEANS DIGITAL ENVIRONMENT YOUTUBE CHANNEL WITH INTERACTIVE FOR SELF-KNOWLEDGE AND THE USE OF ELECTRONIC CALCULATORS ONLINE
}

У статті окреслено основні принципи масового та дистанційного навчання бакалаврів із кібербезпеки в умовах освітньо-цифрового середовища засобами Үоитubе-каналів з інтерактивом для самоперевірки отриманих знань та з використанням електронних онлайнкалькуляторів. Впровадження масового та дистаниійного навчання залучається до набагато ширших тем, теорій та практик у галузі освіти та технологій. Виокремлено методики масового і дистанційного навчання. В електронні онлайн-калькулятори в умовах освітньоцисррового середовища, крім логіки обчислень, числа регістрів пам'яті, набору підтримуваних функиій і можливостей відображення додаються деякі параметри: спосіб програмування визначається мовою, якою складаються програми; технічні обмеження програм, пов'язані з особливостями реалізації командної мови і схемотехніки калькулятора; наявність незалежної пам'яті, тобто можливість тривалого зберігання вмісту оперативної пам'яті в разі виключення калькулятора і наявність або можливість підключення пристроїв для оперативного введення-виведення програм $i$ даних. Визначено, що для програмованих калькуляторів ия особливість є вкрай важливою, бо саме вона визначає витрати часу на приведення калькулятора в робочий стан: у разі тривалого зберігання або можливості швидкого завантаження завчасно підготовленою до використання програми його можна просто включити і працювати, за відсутності незалежної пам'яті кожному сеансу роботи вимушено передує підготовчий процес, що полягає у введенні програми і їі перевірці. Охарактеризовані основні принципи масового та дистаниійного навчання бакалаврів із кібербезпеки в умовах освітньо-цифрового середовища засобами Үоuтube-каналів з інтерактивом для самоперевірки отриманих знань та з використанням електронних онлайн-калькуляторів. До них зараховано принцип гуманістичності підготовки бакалаврів із кібербезпеки в умовах освітньо-цифрового середовища, пріоpumeтності педагогічного підходу в процесі проєктування освітнього процесу в освітньоцифровому середовищі, педагогічної доцільності застосування сучасних засобів щодо підготовки бакалаврів із кібербезпеки, принцип вибору змісту освіти для підготовки бакалаврів із кібербезпеки в умовах освітньо-цисррового середовища, забезпечення захисту інформації в освітньо-цифровому середовищі, стартового рівня освіти бакалаврів із кібербезпеки, відповідності технологій навчання бакалаврів із кібербезпеки в умовах освітньо-цифррового середовища, мобільності підготовки бакалаврів із кібербезпеки в умовах освітньо-цифрового середовища.

Ключові слова: принципи навчання, масове та дистанційне навчання, ҮоuTube-канал; електронний онлайн-калькулятор, бакалавр із кібербезпеки, освітньо-цифрове середовище.

The article outlines the basic principles of mass and distance learning of bachelors in cybersecurity in the educational and digital environment by means of YouTube channels with interactive self-checking of the acquired knowledge and with the use of electronic online calculators. The introduction of mass and distance learning is involved in much broader topics, theories and practices in the field of education and technology. Methods of mass and distance learning are singled out. In electronic online calculators in the educationaldigital environment, in addition to the logic of calculations, the number of memory registers, a set of supported functions and display capabilities, some parameters are added, such as: the method of programming is determined by the language in which programs are composed; technical limitations of the programs connected with features of implementation of command language and circuitry of the calculator; the presence of independent memory, ie the possibility of longterm storage of RAM contents when the calculator is turned off and the presence or possibility of connecting devices for prompt I / O of programs and data. It is determined that for programmable calculators this feature is extremely important, as it determines the time spent on bringing the calculator into working condition: with long-term storage or the ability to quickly load a pre-prepared program, you can simply turn it on and work, in the absence of independent memory. Each session is preceded by a preparatory process, which consists in the introduction of the program and its verification. The basic principles of mass and distance learning of bachelors in cybersecurity in the educational and digital environment by means of YouTube channels with interactive for self-checking of the acquired knowledge and with the use of electronic online calculators are described. These include the principle of humanistic training of bachelors in cybersecurity in the educational-digital environment, the priority of pedagogical approach in the process of designing the educational process in the educational-digital environment, the pedagogical feasibility of modern tools for training bachelors in cybersecurity, the principle of choosing educational content for bachelors in cybersecurity. in the educationaldigital environment, information protection in the educational-digital environment, the starting level of education of bachelors in cybersecurity, compliance of technologies for training bachelors in cybersecurity in the educational-digital environment, mobility of bachelors in cybersecurity in the educational-digital environment.

Key words: principles of training, mass and distance learning; YouTube channel; electronic online calculator; Bachelor of Cyber Security; educational and digital environment. 
Постановка проблеми в загальному вигляді. Сучасні світові тенденції ринку праці окреслюють нові вимоги до конкурентоспроможних компетентних кадрів - фрахівців цифррового простору. Перехід до цифрового світу в умовах масового та дистанційного навчання розширює межі подання та захисту інфрормації, а отже, виникає потреба в якісній сучасній підготовці бакалаврів із кібербезпеки, зокрема в умовах освітньо-цифрового середовища за допомогою відеозасобів з інтерактивом для самоперевірки отриманих знань та сучасних електронних онлайн-калькуляторів. У контексті зазначеного варто підкреслити той фракт, що питання підготовки бакалаврів із кібербезпеки засобами YouTube-каналів 3 інтерактивом для самоперевірки отриманих знань та з використанням електронних онлайн-калькуляторів у сучасних працях світових науковців досліджено мало. Виникає потреба в розробці основних принципів масового та дистанційного навчання бакалаврів із кібербезпеки в умовах освітньо-цифрового середовища засобами ҮouTube-каналів 3 інтерактивом для самоперевірки отриманих знань та з використанням електронних онлайн-калькуляторів.

Аналіз останніх досліджень і публікацій. У своїх дослідженнях Н.В. Абашкіна розкриває принципи розвитку профресійної освіти за кордоном, зокрема щодо освіти бакалаврів. Принцип як світоглядну парадигму морально-ціннісних орієнтацій та самовдосконалення людини розглядає Н.І. Гринчишин. Проблемами масового і дистанційного навчання займалась І.В. Бацуровська. Дослідниця описує методики використання сучасних відеоканалів та технології створення відеолекцій з інтерактивом для самоперевірки знань. Автор Н.А. Доценко розглядає особливості підготовки відеозвітів та окреслює ключові принципи роботи з онлайн-калькуляторами здобувачів вищої освіти інженерних спеціальностей. Але в педагогічній літературі питанню основних принципів масового та дистанційного навчання бакалаврів із кібербезпеки в умовах освітньо-циорового середовища засобами ҮouTube-каналів 3 інтерактивом для самоперевірки отриманих знань та 3 використанням електронних онлайн-калькуляторів приділялась незначна увага.

Мета статті - окреслити основні принципи масового та дистанційного навчання бакалаврів із кібербезпеки в умовах освітньо-циорового середовища засобами YouTube-каналів 3 інтерактивом для самоперевірки отриманих знань та з використанням електронних онлайн-калькуляторів.

Виклад основного матеріалу. Масове та дистанційне навчання закладає в основу роботу 3 MOOC - масовими відкритими онлайн-курсами. MOOC - це цифрова технологія, що є ключовим фрактором у сучасному навчанні бакалаврів, яка закладає в основу навчання від 1000 осіб. Впро- вадження масового та дистанційного навчання залучається до набагато ширших тем, теорій та практик у галузі освіти та технологій. Для такого навчання бакалаврів із кібербезпеки потрібно розробити курс, який ініціює читання, критичний перегляд відеолекцій та структуровану дискусію як основну педагогічну діяльність. Візуальні елементи створюються та використовуються як засіб побудови діалогу та дискусій навколо ключових тем електронного навчання. Учасники в умовах освітньо-цифрового середовища можуть сприяти участі та зацікавлені освітнім контентом.

Масове та дистанційне навчання для бакалаврів із кібербезпеки реалізується з використанням ресурсів та технологій глобальної мережі Інтернет в умовах освітньо-цифрового середовища. За умов такого навчання можуть використовуватися різноманітні методи надання навчальної інфрормації. $€$ кілька організаційно-методичних методик масового і дистанційного навчання.

1. Навчання за типом екстернату. Це навчання, орієнтоване на екзаменаційні вимоги вищих навчальних закладів, воно призначалося для студентів, які з якихось причин не могли відвідувати стаціонарні навчальні заклади.

2. Навчання на базі одного університету. Це вже ціла система навчання для студентів, які навчаються не стаціонарно, а на відстані, заочно або дистанційно, тобто на основі нових інформаційних технологій, включаючи комп'ютерні телекомунікації. Такі програми для одержання різноманітних дипломів розроблені в багатьох провідних університетах миру.

3. Співробітництво кількох навчальних закладів. Таке співробітництво в підготовці програм заочного дистанційного навчання дає змогу зробити їх більш професійно якісними і менш дорогими.

Сучасне дистанційне навчання бакалаврів із кібербезпеки в умовах освітньо-цифрового середовища будується на використанні таких основних елементів:

- середовища передачі інфрормації (електронна пошта, цифрові інформаційні комунікаційні мережі);

- методів, залежних від технічного середовища, обміну інорормацією.

Доцільною $€$ інтерактивна взаємодія викладача 3 бакалаврами 3 кібербезпеки за допомогою інформаційних комунікаційних мереж, з яких масово виділяється середовище Інтернет-користувачів. Під час дистанційного навчання використовуються такі основні елементи, як дистанційні курси, вебсторінки й сайти, електронна пошта, форуми й блоги, чат і ICQ, теле- і відеоконоеренції, віртуальні класні кімнати та інше.

В електронні онлайн-калькулятори в умовах освітньо-цифрового середовища, крім логіки обчислень, числа регістрів пам'яті, набору під- 
тримуваних фрункцій і можливостей відображення додаються деякі параметри. Окреслимо їх.

- Спосіб програмування визначається мовою, якою складаються програми.

- Технічні обмеження програм, пов'язані 3 особливостями реалізації командної мови і схемотехніки калькулятора. Наприклад, кількість підпрограм, які можуть бути вкладені одна в одну, наявність або відсутність непрямої адресації командною мовою.

- Наявність незалежної пам'яті, тобто можливість тривалого зберігання вмісту оперативної пам'яті в разі виключення калькулятора і наявність або можливість підключення пристроїв для оперативного введення-виведення програм і даних. Для програмованих калькуляторів ця особливість $є$ вкрай важливою, бо саме вона визначає витрати часу на приведення калькулятора в робочий стан: у разі тривалого зберігання або можливості швидкого завантаження завчасно підготовленої до використання програми його можна просто включити і працювати, за відсутності незалежної пам'яті кожному сеансу роботи вимушено передує підготовчий процес, що полягає у введенні програми і її перевірці.

Електронні онлайн-калькулятори в умовах освітньо-циоррового середовища дають змогу лише зберігати і багаторазово використовувати послідовності операцій, багаторазово виконувати обчислення за одним і тим самим фрормулам без повторного введення цих фрормул (Додаток 5, рис. 29-31).

YouTube-канали 3 інтерактивом для самоперевірки отриманих знань - це простий спосіб для бакалаврів із кібербезпеки перевірити рівень отриманих знань у режимі реального часу. Незалежно від того, чи передається поточна подія, чи викладається заняття, чи проводиться семінар, завжди є інструменти, які допоможуть вам керувати потоком та взаємодіяти з глядачами в режимі реального часу.

Прямий ефір заздалегідь треба планувати. Увімкнення трансляції вперше доцільно не перевищувати однієї години. Інші трансляції YouTubeканалів мають уміщувати інтерактивні елементи для самоперевірки отриманих знань: тестові питання, можливість висловити власну думку, процитувати науковий погляд. Після ввімкнення потік може миттєво перейти в режим активного перегляду. Здійснювати трансляції в прямому ефрірі на YouTube можна за допомогою вебкамери, мобільного пристрою та передачі кодера. Вебкамера та мобільний телефон вважаються чудовими варіантами для початківців і дозволяють швидко жити, хоча потокове кодування ідеально підходить для більш просунутих прямих трансляцій . Для того, щоб здійснити трансляцію через вебкамеру, бакалаврам із кібербезпеки потрібно перейти в ефір без необхідності використання кодера. Потокове передавання на мобільному пристрої дає змогу передавати трансляцію з програми YouTube. Потокове передавання кодера або енкодера дають змогу захоплювати вміст, включаючи робочий стіл, камеру, мікрофрон тощо, та надсилати його на YouTube Live, щоб передавати його аудиторії. Коли потік у прямому ефірі, можна спілкуватися 3 аудиторією бакалаврів із кібербезпеки за допомогою чату в прямому ефрірі та ділитися посиланням на прямий потік на платформах соціальних медіа за допомогою інструменту SHARE YouTube. Весь вміст у прямому есрірі має відповідати етичним правилам та умовам користування YouTube.

На основі досліджень відомих учених [1; 4-6] окреслимо основні принципи масового та дистанційного навчання бакалаврів із кібербезпеки в умовах освітньо-цифрового середовища засобами YouTube-каналів 3 інтерактивом для самоперевірки отриманих знань та 3 використанням електронних онлайн-калькуляторів:

1. Принцип гуманістичності підготовки бакалаврів із кібербезпеки в умовах освітньо-цифрового середовища. Цей принцип $є$ визначальним у системі безперервної інтенсивної підготовки бакалаврів із кібербезпеки і посилюється стосовно використання освітньо-цифрового середовища. Його суть полягає у спрямованості підготовки та освітнього процесу загалом до бакалаврів із кібербезпеки, у створенні максимально сприятливих умов для оволодіння ними соціально накопиченого досвіду в змісті освіти, засвоєнні вибраної професії для розвитку і проявах творчої індивідуальності, високих громадянських, моральних, інтелектуальних якостей, що забезпечували б соціальну захищеність, безпечне та коморортне існування.

2. Принцип пріоритетності педагогічного підходу в прочесі проєктування освітнього процесу в освітньо-цифровому середовищі. Суть названого принципу полягає в тому, що проєктування навчання в такому середовищі необхідно починати з розробки теоретичних концепцій, створення дидактичних моделей тих явищ, що планується реалізувати. Досвід комп'ютеризації дає змогу стверджувати, що коли пріоритетною $€$ педагогічна сторона, система $€$ ефрективнішою.

3. Принцип педагогічної доцільності застосування сучасних засобів щодо підготовки бакалаврів із кібербезпеки. Він вимагає педагогічної оцінки ефективності кожного кроку проєктування та створення освітньо-цифрового середовища. Тому на перший план необхідно ставити відповідне змістовне наповнення навчальних курсів i освітніх послуг.

4. Принцип вибору змісту освіти для підготовки бакалаврів із кібербезпеки в умовах освітньо-цифрового середовища. Зміст дистанційної 
освіти в умовах освітньо-цифрового середовища має відповідати нормативним вимогам Державного освітнього стандарту і вимогам ринку.

5. Принцип забезпечення захисту інорормації в освітньо-цифровому середовищі. Необхідно передбачати організаційні й технічні засоби безпечного та конфіденційного зберігання, передачі і використання відомостей, забезпечення їх безпеки під час зберігання, передачі й використання.

6. Принцип стартового рівня освіти бакалаврів яз кібербезпеки. Ефективне дистанційне навчання вимагає певного набору знань, вмінь, навичок. Наприклад, для продуктивного навчання бакалаври 3 кібербезпеки мають ознайомитися 3 науковими основами самостійної навчальної праці, володіти певними навичками роботи 3 комп'ютером та ін.

7. Принцип відповідності технологій до навчання бакалаврів із кібербезпеки в умовах освітньо-циорового середовища. Технології навчання мають бути адекватними моделям освітньо-цифрового середовища. Як організаційні форми навчання використовуються лекції, семінарські і практичні заняття, імітаційні або ділові ігри, лабораторні заняття, самостійна робота, виробнича практика, курсові і дипломні роботи, контроль засвоєння знань тощо. У процесі становлення освітньо-цифрового середовища можуть з'явитися нові моделі, що за необхідності можна внести до нього. Як організаційні фрорми навчання використовуватимуться комп'ютерні конореренції, телеконференції, телеконсультації, проєктні роботи та ін.

8. Принцип мобільності підготовки бакалаврів із кібербезпеки в умовах освітньо-цифрового середовища. Він полягає в створенні інформаційних мереж, баз і банків знань та даних для освітньо-цифрового середовища, що дадуть бакалаврам із кібербезпеки змогу коригувати або доповнювати свою освітню програму в необхідному напрямі за відсутності відповідних послуг у вищому навчальному закладі, де він навчається. При цьому вимагається збереження інфрормаційної інваріантної освіти, що забезпечує перехід 3 університету до університету на навчання за спорідненими або іншими напрямами.

Висновки. Таким чином, основні принципи масового та дистанційного навчання бакалаврів із кібербезпеки в умовах освітньо-цифрового середовища засобами YouTube-каналів з інтерактивом для самоперевірки отриманих знань та 3 використанням електронних онлайн-калькуляторів $€$ невід'ємним аспектом сучасної професійної підготовки. Це дає змогу регламентувати процес підготовки бакалаврів із кібербезпеки та забезпечити якість їх підготовки в умовах освітньо-цифрового середовища. Перспективами подальших розробок $\epsilon$ впровадження YouTube-каналів з інтерактивом для самоперевірки отриманих знань та з використанням електронних онлайн-калькуляторів у систему підготовки фрахівців із кібербезпеки та статистична перевірка отриманих результатів.

\section{БІБЛІОГРАФІЧНИЙ СПИСОК:}

1. Бацуровська І.В. Освітньо-наукова підготовка магістрів в умовах масових відкритих дистанційних курсів : монографрія. Херсон: Грінь Д.С., 2016. 511 с.

2. Самойленко О.О. Підготовка бакалаврів із кібербезпеки в умовах освітньо-цифрового середовища. Київ : Гадяк Ж.В., 2020. 411 с.

3. Бацуровська І.В. Методика підготовки відеолекцій для масових відкритих дистанційних курсів. Херсон : Гринь Д.С., 2015.

4. Абашкіна Н.В. Принципи розвитку профресійної освіти в Німеччині. Київ, 1998.

5. Гринчишин Н.І. Принцип діалогу як світоглядна парадигма морально-ціннісних орієнтацій та самовдосконалення людини. Аксіологічні аспекти трансфрормації сучасного українського суспільства : матеріали Всеукр. наук.-практ. конф., Івано-Франківськ, 2007.

6. Доценко Н.А. Особливості підготовки відео звітів з практики. Від знаннєвої парадигми до компетентнісної: реалії, перспективи. Херсон, 2017. 